\title{
Effect of Hot Water Blanching Time and Drying Temperature on the Thin Layer Drying Kinetics of and Anthocyanin Degradation in Black Carrot (Daucus carota L.) Shreds
}

\author{
Umar Garba ${ }^{1,2}$, Sawinder Kaur ${ }^{1 *}$, Sushma Gurumayum ${ }^{3}$ and Prasad Rasane ${ }^{1}$ \\ ${ }^{1}$ Department of Food Technology and Nutrition, School of Agriculture, Lovely Professional University, \\ Phagwara, 144402 Punjab, India \\ ${ }^{2}$ Department of Agricultural Bioengineering Technology, Audu Bako College of Agriculture, \\ Dambatta, Kano State, Nigeria \\ ${ }^{3}$ Department of Microbiology and Bioprocess Engineering, School of Biotechnology, \\ Lovely Professional University, Phagwara, 144402 Punjab, India
}

Received: July 25, 2014

Accepted April 21, 2015

\begin{abstract}
Summary
This study was conducted to investigate the effect of blanching treatment $\left(98^{\circ} \mathrm{C}\right.$ for 3 and $6 \mathrm{~min}$ ) and air drying temperature of 40,50 and $60^{\circ} \mathrm{C}$ on the thin layer drying characteristics such as drying time, drying rate constant, effective moisture diffusivity and activation energy, as well as on anthocyanin content of black carrot shreds. It was observed that drying temperature affected the drying rate but blanching did not have an effect on drying time. Three thin layer drying models, i.e. Page, Lewis and Henderson-Pabis were evaluated. The goodness of these models was evaluated based on the coefficient of determination $\left(\mathrm{R}^{2}\right)$, root mean square error, reduced chi square $\left(\chi^{2}\right)$ and standard error. Page model showed the best fit to the drying data. The effective diffusivity ranges of $1.4 \cdot 10^{-9}$ to $2.6 \cdot 10^{-9}$ $\mathrm{m}^{2} / \mathrm{s}, 1.3 \cdot 10^{-9}$ to $2.1 \cdot 10^{-9} \mathrm{~m}^{2} / \mathrm{s}$ and $1.5 \cdot 10^{-9}$ to $2.2 \cdot 10^{-9} \mathrm{~m}^{2} / \mathrm{s}$ after 3 or 6 min of blanching and control samples respectively were calculated using Fick's second law. The activation energy of $37.5,26.0$ and $34.6 \mathrm{~kJ} /(\mathrm{mol} \cdot \mathrm{K})$ of the control samples and samples blanched for 3 or 6 min respectively was determined from the Arrhenius plot. The blanching treatment affected the anthocyanin content to a great extent. The anthocyanin content of $(231.7 \pm 2.9)$ and $(278.8 \pm 7.8) \mathrm{mg}$ per $100 \mathrm{~g}$ was recorded in samples blanched for 3 and $6 \mathrm{~min}$ and then dried at $60{ }^{\circ} \mathrm{C}$, and $(153.0 \pm 4.3)$ and $(247.0 \pm 5.5) \mathrm{mg}$ per $100 \mathrm{~g}$ was recorded at $40^{\circ} \mathrm{C}$ as compared to the control of $(580.1 \pm 1.3)$ at $60^{\circ} \mathrm{C}$ and $(466.7 \pm 1.1) \mathrm{mg}$ per $100 \mathrm{~g}$ at $40^{\circ} \mathrm{C}$.
\end{abstract}

Key words: black carrot, blanching, effective diffusivity, activation energy, drying rate, thin layer model, anthocyanin content

\section{Introduction}

Carrot is one of the most common vegetables used for human nutrition due to its high nutritive value in terms of vitamin and fibre contents (1). Statistics has shown that China is currently the largest producer of carrots with almost one third of all carrots bought and sold worldwide. Russia is the second largest carrot producer, with the United States following a close third. Many European countries produce substantial amounts of carrots (over 400000 metric tonnes) and Turkey, Mexico, India, Indonesia, Australia and Canada are also among the important carrot producers in the world (2). Carrot is an excellent source of $\beta$-carotenes, reported to prevent cancer, 
vitamin A and potassium, and it contains cholesterol-lowering pectin, vitamin $\mathrm{C}$, vitamin $\mathrm{B}_{6}$, thiamine, folic acid and magnesium. With high moisture content, fresh carrots are sensitive to microbial spoilage, even when refrigerated and under controlled atmosphere storage conditions (3). Drying is one of the most frequently used processing methods to prolong the shelf life of carrots. Dried carrots are used in instant dehydrated soups and in the form of powder in desserts and sauces (4). Black or purple carrots with high anthocyanin content have a possibility to be used in food, nutraceutical and pharmaceutical preparations. The red, purple and blue carrots have a potential as colourants in food because of their low toxicity (5). Black carrot is a seasonal fruit which is highly perishable, especially in its fresh form. However, it is unique because of its high phytochemical content, particularly of anthocyanins and other phenolic acids, which play an important role in reducing the risk of disease. This phytochemical diversity offers many opportunities in functional food and nutraceutical research.

Drying of material with high moisture content involves a complicated process of simultaneous heat and mass transfer. Using thin layer drying the sample is dried in a single layer, which results in faster removal of moisture (6). A number of studies have been conducted on drying kinetics of different fruits and vegetables such as apricot (7), seedless grape (8), sweet potato (9) and yam slices (10), so that they can be preserved by reducing the moisture content with minimal loss in valuable phytonutrients along with chemical and microbiological stability. The dried product becomes an important raw material for many processed ready-to-eat food products. Blanching is an essential thermal treatment applied to agricultural products prior to any preservation process (such as drying, canning, etc.) in order to inactivate enzymes such as polyphenoloxidases and peroxidase, which cause deterioration reactions, off-flavour and undesirable changes in colour (11). The effect of blanching and drying temperature $\left(50-70{ }^{\circ} \mathrm{C}\right)$ on the drying kinetics of persimmon was studied under the hot air conditions (12). It was reported that both temperature and blanching affect the drying time. In thin layer drying of sweet potato slices in hot air convective dryer at $50-80{ }^{\circ} \mathrm{C}$ using different pretreatments, modified Page model was found to be the best fitted to describe drying behaviour; and higher activation energy of the control sample was recorded (13).

The present study was therefore undertaken to determine the effect of air drying temperature on the thin layer drying characteristics of black carrot shreds in a tray dryer. The best mathematical model to obtain the characteristic drying curves was selected. Moreover, the effect of blanching and drying temperatures on anthocyanin content was studied.

\section{Materials and Methods}

\section{Sample preparation}

The fresh and ripe black carrots (Daucus carota L.) were obtained from Lovely Professional University farm, Punjab, India. Samples were stored at refrigerated tem- perature before use. They were manually peeled using a knife (Crystal Cook-N, Mumbai, India) and grated with manual grater to get the desired thickness of $2 \mathrm{~mm}$.

\section{Pretreatment of carrot samples}

Blanching was done using a modified procedure. The samples were immersed in a thermostatic water bath at $(98 \pm 1){ }^{\circ} \mathrm{C}$ for previously determined time of 3 and $6 \mathrm{~min}$ (14). The ratio of sample mass to water volume was $150 \mathrm{~g}$ of fresh sample per $300 \mathrm{~mL}$. During the isothermal heat treatment, the temperature was controlled with a thermometer. After blanching, the samples were drained to remove the excess water. The experiment was done in triplicate, and unblanched sample was taken as control.

\section{Drying equipment and procedure}

The black carrot samples were subjected to drying in laboratory-scale tray dryer (Labfit India Pvt. Ltd, Ahmadabad, India). The dryer has five sets of trays, equipped with a fan and the temperature regulator. Drying experiment was conducted at 40,50 and $60^{\circ} \mathrm{C}$ and samples were taken out of the dryer and weighed on a digital balance at intervals of $15 \mathrm{~min}$ for the first $1.5 \mathrm{~h}$ followed by 30-minute intervals until moisture content of $4-8 \%$ was obtained and when no further change in moisture content was observed. The moisture content of the samples was converted to moisture content on dry mass basis (15) using the standard formula:

$$
w(\text { moisture })=\left(m-m_{\mathrm{d}}\right) / m_{\mathrm{d}}
$$

where $w$ is the moisture content on dry mass basis, $m$ is the mass of sample and $m_{\mathrm{d}}$ is the mass of dry matter in the sample.

\section{Interpretation of drying data}

The data obtained from the drying experiment were analysed using three common models (16) as shown in the following equations:

$$
\begin{gathered}
\text { Page model: } \mathrm{MR}=\frac{\mathrm{M}_{\mathrm{t}}-\mathrm{M}_{\mathrm{e}}}{\mathrm{M}_{\mathrm{t}}-\mathrm{M}}=\exp \left(-K t^{\mathrm{N}}\right) \\
\text { Lewis model: } \mathrm{MR}=\frac{\mathrm{M}-\mathrm{M}_{\mathrm{e}}}{\mathrm{M}_{\mathrm{t}}-\mathrm{M}_{\mathrm{e}}}=\exp (-K t) \\
\text { Henderson-Pabis model: } \mathrm{MR}=\frac{\mathrm{M}_{\mathrm{t}}-\mathrm{M}_{\mathrm{e}}}{\mathrm{M}_{\mathrm{t}}-\mathrm{M}_{\mathrm{e}}}=a \exp (-K t)
\end{gathered}
$$

where MR is the moisture ratio, $M_{t}$ is the moisture at any time $t$ during drying, $\mathrm{M}_{\mathrm{i}}$ is the initial moisture content, $\mathrm{M}_{\mathrm{e}}$ is the equilibrium moisture content, $K$ is the drying rate constant, while $N$ is the drying constant for Page model and $a$ is the drying constant for Henderson-Pabis model.

The experimental values for the thin layer drying models were determined empirically from the normalized drying curves at different temperatures, which were evaluated based on the coefficient of regression $\left(\mathrm{R}^{2}\right)$. The normalized models are shown in the following equations:

$$
\begin{gathered}
\text { Page model: } \ln [-\ln \mathrm{MR}]=\ln k+N \ln t \\
\text { Lewis model: } \ln \mathrm{MR}=-k t+1
\end{gathered}
$$


Henderson-Pabis model: $\ln \mathrm{MR}=-k \cdot t+\ln a$

where the drying constants $k$ and $a$ are determined from the slope and intercept of the $\ln (-\ln \mathrm{MR})$ vs. $\ln t$ curve, respectively.

The intercept for the Lewis equation was set equal to 1. The equilibrium moisture content $\left(\mathrm{M}_{\mathrm{e}}\right)$ was obtained by extending the drying time until no measurable mass loss was observed.

The fitness of each model was evaluated based on the root mean square error (RMSE), chi square $\left(\chi^{2}\right)$ and relative percentage error (PE). The predicted moisture ratio was compared to the experimental moisture ratio using RMSE and $\chi^{2}$ as shown below $(16,17)$.

$$
\begin{gathered}
\text { RMSE }=\sqrt{\frac{1}{N} \sum_{i=1}^{N}\left(\mathrm{M}_{\exp (\mathrm{i})}-\mathrm{M}_{\text {cal }(\mathrm{i})}\right)^{2}} \\
\chi^{2}=\frac{1}{N-n} \sum_{i=1}^{N}\left(\mathrm{M}_{\exp (\mathrm{i})}-\mathrm{M}_{\text {cal }(\mathrm{i})}\right)^{2} \\
\mathrm{PE}=\sqrt{\frac{\sum\left(\mathrm{M}_{\exp }-\mathrm{M}_{\text {cal }}\right)}{N-n}}
\end{gathered}
$$

where $N$ is the number of parameters of the model, $n$ is the number of observations, $M_{\exp (i)}$ is the experimental moisture ratio at the ith observation, and $\mathrm{M}_{\text {cal (i) }}$ is the calculated moisture ratio at the ith observation.

As the RMSE and $\chi^{2}$ approach zero, the prediction is closer to the experimental data. RMSE and $\chi^{2}$ compare the differences between the predicted moisture ratios and the experimental moisture ratios, while percentage error (PE) compares the absolute differences between the predicted moisture contents and the experimental moisture contents throughout the drying period $(16,17)$.

\section{Effective moisture diffusivity and activation energy}

Most drying processes of food material occur in the falling-rate period, and the transfer of moisture during the drying process is controlled by internal diffusion (18). Fick's second law of diffusion has been widely used to describe the drying process during the falling-rate period of most of the biological materials (19), as shown in the equation below:

$$
\frac{\delta \mathrm{M}}{\delta \mathrm{t}}=\nabla\left[D_{\text {eff }}(\nabla \mathrm{M})\right]
$$

where $D_{\text {eff }}$ is the effective moisture diffusivity $\left(\mathrm{m}^{2} / \mathrm{s}\right)$, representing the conductive term of all moisture transfer mechanisms and it is determined from experimental drying curves (19). This equation can be applied for different regularly shaped bodies such as cylindrical, spherical and rectangular products (20), while Eq. 12 can be used for materials with slab geometry by assuming initial moisture distribution (6), negligible shrinkage, constant temperature gradients and diffusion coefficients $(3,10)$ :

$$
\mathrm{MR}_{\mathrm{i}}=\frac{3}{\pi^{2}} \sum_{n=0}^{\infty} \frac{1}{(2 b+1)^{2}} \exp \left(-\frac{(2 n+1)^{2} \pi^{2} D_{\text {eff }} t}{4 L_{0}^{2}}\right)
$$

where $D_{\text {eff }}$ is the effective diffusivity $\left(\mathrm{m}^{2} / \mathrm{s}\right), L_{0}$ is the half-value thickness of slab in the sample $(\mathrm{m})$ and $b$ is a positive integer. For longer drying period, Eq. 10 can be further simplified to only the first term of series $(6,19)$ and can be written as follows:

$$
\ln \mathrm{MR}=\ln \frac{8}{\pi^{2}}-\frac{\pi^{2} D_{\text {eff }} t}{4 L_{0}^{2}}
$$

The effective moisture content was determined from the slope of the $\ln$ MR vs. time. The slope was calculated as:

$$
\begin{gathered}
\text { Slope }=\frac{\pi^{2} D_{\text {eff }}}{4 L_{0}^{2}} \\
D_{\text {eff }}=\frac{4 L_{0}^{2}}{\left(\pi^{2}\right) \cdot \text { slope }}
\end{gathered}
$$

where

$$
\text { Slope }=\frac{\left(\ln \mathrm{MR}_{2}-\ln \mathrm{MR}_{1}\right)}{t_{2}-t_{1}}
$$

where $\mathrm{MR}_{1}$ is the moisture ratio at time $t_{1}$ taken from the graph, and $\mathrm{MR}_{2}$ is the moisture ratio at time $t_{2}$ taken from the graph.

\section{Activation energy to derive the temperature dependence of effective diffusivity}

Arrhenius equation was used to describe the temperature dependence of the effective diffusivity (6) as follows:

$$
D_{\text {eff }}=D_{0} \exp \left(-\frac{E_{\mathrm{a}}}{R T}\right)
$$

where $D_{0}$ is the pre-exponential factor of the Arrhenius equation $\left(\mathrm{m}^{2} \cdot \mathrm{s}\right), E_{\mathrm{a}}$ is the activation energy $(\mathrm{kJ} / \mathrm{mol}), R$ is the universal gas constant with the value of $8.314 \mathrm{~J} /$ $(\mathrm{mol} \cdot \mathrm{K})$, and $T$ is the absolute temperature $(\mathrm{K})$. The activation energy is determined from the slope of the Arrhenius plot, $\ln D_{\text {eff }}$ vs. $1 / T$ :

$$
\text { Slope }=\frac{E_{\mathrm{a}}}{R}
$$

\section{Anthocyanin content}

The anthocyanin content was analysed according to the procedure given by Srivastava and Kumar (21). It is based on the extraction of anthocyanins from the fresh black carrot sample with ethanolic $\mathrm{HCl}$ and then measuring the colour at the maximum absorption wavelength of $535 \mathrm{~nm}$. The anthocyanin content can be estimated from the molar absorption coefficient $\left(\varepsilon_{\max }\right)$ or by establishing the average coefficient for each pigment. The data were subjected to analysis of variance and Tukey's test using SPSS v. 22 software (22). The effect of drying temperatures $\left(40,50\right.$ and $\left.60^{\circ} \mathrm{C}\right)$ and blanching pretreatment (no blanching and blanching at $98^{\circ} \mathrm{C}$ for 3 or $6 \mathrm{~min}$ ) on anthocyanin content of black carrot was evaluated.

\section{Results and Discussion}

\section{Drying characteristics of black carrot shreds}

The initial moisture content of black carrots was 890.9 $\%$ on dry basis, which reached a final level of 3-8 \% when drying $150 \mathrm{~g}$ of sample at $40-60{ }^{\circ} \mathrm{C}$. The drying curve of the control and blanched samples in accordance with the Page model is shown in Figs. 1-3. The drying time to reach the equilibrium moisture content was 240, 180 and 150 min for the control samples, and samples blanched for 3 and 6 min at drying air temperatures of 40,50 and $60^{\circ} \mathrm{C}$ 
respectively. However, similar drying time was observed among control (Fig. 1) and blanched (Figs. 2 and 3) samples at all the drying temperatures. Similar finding was observed when persimmon slices were blanched for 3-10 min (12), and when sweet potatoes were blanched and dried at $70{ }^{\circ} \mathrm{C}$ as compared to the control (unblanched) sample (13). This contradicts the findings of Agarry et al.

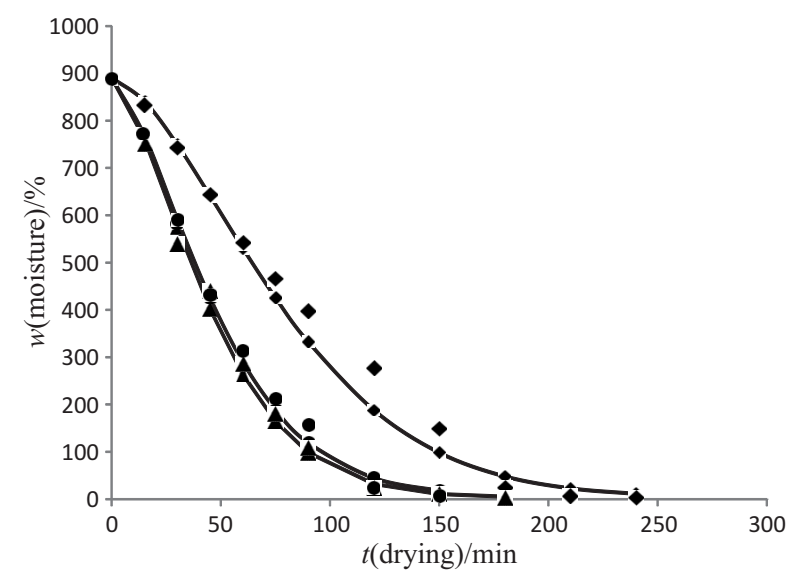

Fig. 1. Drying curve of the sample of unblanched black carrot shreds at $40(\bullet), 50(\Delta)$ and $60^{\circ} \mathrm{C}(\bullet)$ obtained using Page model

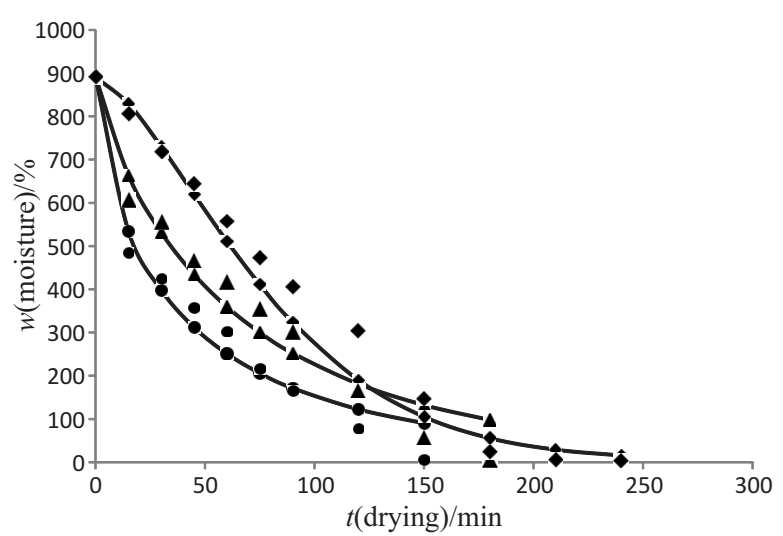

Fig. 2. Drying curve of the sample of black carrot shreds blanched for $3 \mathrm{~min}$ at $40(\bullet), 50(\boldsymbol{\bullet})$ and $60^{\circ} \mathrm{C}(\bullet)$ obtained using Page model

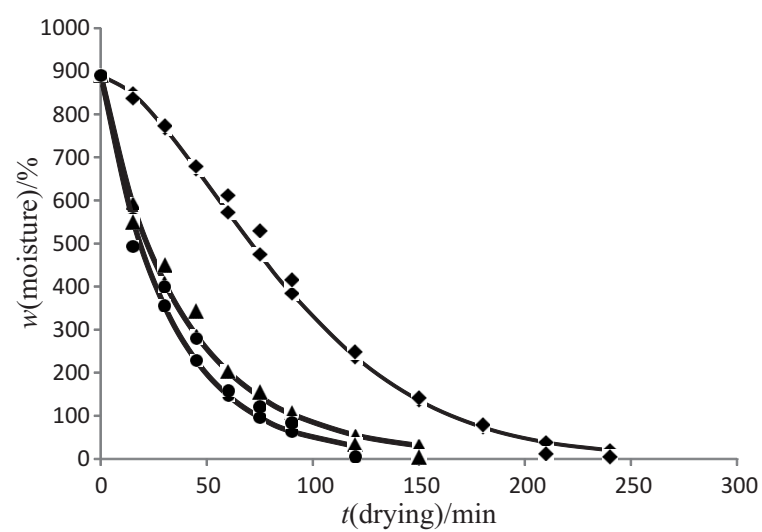

Fig. 3. Drying curve of the sample of black carrot shreds blanched for 6 min at $40(\bullet), 50(\bullet)$ and $60{ }^{\circ} \mathrm{C}(\bullet)$ obtained using Page model
(23), who indicate that blanching of pineapple slices at $60-80{ }^{\circ} \mathrm{C}$ for $3-5 \mathrm{~min}$ resulted in shorter drying time than the control (unblanched) sample. These contradictions might be due to the differences in the used samples. The moisture content decreases continuously with the increase in temperature.

\section{Drying time and drying rate}

With each increase in temperature by $10^{\circ} \mathrm{C}$, the drying time decreases $(16,24)$. The drying has been found to occur during the falling-rate periods as observed by Maskan (25) on kiwifruit and Aghbashlo et al. (1) on carrots. A continuous increase in the drying rate was observed with the increase in drying temperature. This increase is expected as the higher drying air temperature leads to a greater moisture evaporation rate at the food/air interface. The higher moisture evaporation rate causes moisture to diffuse at a higher rate from the internal regions of the black carrot to the surface, thereby increasing the diffusion coefficients. Similar trend has been reported in various published literature $(1,26)$. It was observed that drying rate constants were higher in control and the samples blanched for $3 \mathrm{~min}$ at all temperatures. The higher value of drying rate constant recorded at the beginning of drying was due to high moisture content (21). The values of the drying rate constants obtained from the Page, Lewis and Henderson-Pabis models are given in Table 1.

\section{Evaluation of the drying models}

The experimental moisture content obtained during the drying experiment was converted to moisture ratio (MR) and then fitted to the three different models. Based on the statistical results of reduced chi square $\left(\chi^{2}\right)$, root mean square error (RMSE) and relative percentage error (PE) of the different models tested on control and blanched samples, Page model was found to be the best fitted. Similar findings have been reported by many researchers $(1,27,28)$. The results are shown in Table 2 . It can be observed that the RMSE, $\chi^{2}$ and PE values are lower in the Page model. The $\chi^{2}$ values are, however, slightly lower for all the blanched samples dried at 40 and $60{ }^{\circ} \mathrm{C}$ compared to the control. In the sample blanched for $3 \mathrm{~min}$, Henderson-Pabis model exhibited lower values of PE than that of Page model.

\section{Interpretation of the effective moisture diffusivity and activation energy data}

The moisture diffusion during drying and the activation energy were determined by Fick's diffusion model and Arrhenius model separately (Eqs. 12 and 17). Linearization of Eq. 12 allowed the estimation of the effective moisture diffusivity $\left(D_{\text {eff }}\right)$ of both blanched and unblanched samples. The effective diffusivity from $1.4 \cdot 10^{-9}$ to $2.6 \cdot 10^{-9} \mathrm{~m}^{2} / \mathrm{s}, 1.5 \cdot 10^{-9}$ to $2.2 \cdot 10^{-9} \mathrm{~m}^{2} / \mathrm{s}$ and $1.3 \cdot 10^{-9}$ to $2.1 \cdot 10^{-9} \mathrm{~m}^{2} / \mathrm{s}$ was obtained in the control and in samples blanched for 3 and 6 min (Table 3). In all the cases, the effective diffusivity increased with the increase in the drying air temperature (27). Higher diffusivity values of 2.5 and $2.6 \mathrm{~m}^{2} / \mathrm{s}$ were recorded in the control samples at 50 and $60{ }^{\circ} \mathrm{C}$, and lower values were recorded at all the tem- 
Table 1. Empirical constants of Page, Lewis and Henderson-Pabis models

\begin{tabular}{|c|c|c|c|c|c|c|c|c|c|}
\hline \multirow{2}{*}{ Sample } & \multirow{2}{*}{$\frac{\text { Temperature }}{{ }^{\circ} \mathrm{C}}$} & \multicolumn{3}{|c|}{ Page model } & \multicolumn{2}{|c|}{ Lewis model } & \multicolumn{3}{|c|}{ Henderson-Pabis model } \\
\hline & & $k / \mathrm{h}$ & $N$ & $\mathrm{R}^{2}$ & $k / \mathrm{h}$ & $\mathrm{R}^{2}$ & K & $a$ & $\mathrm{R}^{2}$ \\
\hline \multirow{3}{*}{ Control } & 40 & 0.57 & 1.40 & 0.99 & 1.11 & 0.92 & 1.11 & 1.55 & 0.92 \\
\hline & 50 & 1.10 & 1.40 & 0.97 & 1.94 & 0.88 & 1.94 & 1.82 & 0.88 \\
\hline & 60 & 1.35 & 1.35 & 0.97 & 2.00 & 0.94 & 2.00 & 2.56 & 0.94 \\
\hline \multirow{3}{*}{ BL3 } & 40 & 0.77 & 1.12 & 0.99 & 0.96 & 0.97 & 0.96 & 1.18 & 0.97 \\
\hline & 50 & 0.91 & 1.03 & 0.97 & 1.32 & 0.95 & 1.32 & 1.20 & 0.95 \\
\hline & 60 & 1.41 & 1.18 & 0.99 & 1.67 & 0.97 & 1.67 & 0.84 & 0.97 \\
\hline \multirow{3}{*}{ BL6 } & 40 & 0.45 & 1.59 & 0.98 & 1.15 & 0.86 & 1.15 & 1.76 & 0.86 \\
\hline & 50 & 0.82 & 1.61 & 0.99 & 1.40 & 0.95 & 1.40 & 1.42 & 0.95 \\
\hline & 60 & 0.98 & 1.56 & 0.99 & 1.72 & 0.90 & 1.72 & 1.57 & 0.90 \\
\hline
\end{tabular}

$\mathrm{R}^{2}=$ regression coefficient, $k=\mathrm{drying}$ rate constant, $N=\mathrm{drying}$ constant for Page model and $a=\mathrm{drying}$ constant for Henderson-Pabis model, BL3=samples blanched at $98{ }^{\circ} \mathrm{C}$ for $3 \mathrm{~min}$, BL6=samples blanched at $98{ }^{\circ} \mathrm{C}$ for $6 \mathrm{~min}$

Table 2. Statistical results obtained using different models of thin-layer drying of black carrot shreds

\begin{tabular}{|c|c|c|c|c|c|c|c|c|c|c|}
\hline \multirow{2}{*}{ Sample } & \multirow{2}{*}{$\frac{\text { Temperature }}{{ }^{\circ} \mathrm{C}}$} & \multicolumn{3}{|c|}{ Page model } & \multicolumn{3}{|c|}{ Lewis model } & \multicolumn{3}{|c|}{ Henderson-Pabis model } \\
\hline & & RMSE & $\chi^{2} \cdot 10^{-2}$ & $\mathrm{PE}$ & RMSE & $\chi^{2} \cdot 10^{-2}$ & PE & RMSE & $\chi^{2} \cdot 10^{-2}$ & PE \\
\hline \multirow{3}{*}{ Control } & 40 & 0.03 & 0.08 & 0.03 & 0.17 & 3.19 & 0.19 & 0.19 & 4.16 & 0.20 \\
\hline & 50 & 0.04 & 0.15 & 0.04 & 0.19 & 4.17 & 0.22 & 0.28 & 10.02 & 0.32 \\
\hline & 60 & 0.04 & 0.17 & 0.04 & 0.12 & 1.69 & 0.14 & 0.59 & 45.03 & 0.67 \\
\hline \multirow{3}{*}{ BL3 } & 40 & 0.02 & 0.04 & 0.02 & 0.06 & 0.40 & 0.07 & 0.06 & 0.45 & 0.02 \\
\hline & 50 & 0.05 & 0.36 & 0.06 & 0.07 & 0.51 & 0.08 & 0.09 & 0.91 & 0.06 \\
\hline & 60 & 0.03 & 0.08 & 0.03 & 0.19 & 0.45 & 0.07 & 0.04 & 0.23 & 0.03 \\
\hline \multirow{3}{*}{ BL6 } & 40 & 0.03 & 0.06 & 0.03 & 0.23 & 5.73 & 0.25 & 0.26 & 8.21 & 0.29 \\
\hline & 50 & 0.04 & 0.19 & 0.04 & 0.16 & 2.93 & 0.18 & 0.15 & 3.26 & 0.17 \\
\hline & 60 & 0.03 & 0.10 & 0.03 & 0.18 & 3.73 & 0.03 & 0.21 & 5.64 & 0.24 \\
\hline
\end{tabular}

RMSE=root mean square error, $\mathrm{PE}=$ relative percentage error, $\chi^{2}=$ reduced chi square, $\mathrm{BL} 3=$ samples blanched at $98^{\circ} \mathrm{C}$ for $3 \mathrm{~min}$, BL6=samples blanched at $98^{\circ} \mathrm{C}$ for $6 \mathrm{~min}$

Table 3. Effective diffusivity in control and blanched black carrot samples after drying

\begin{tabular}{|c|c|c|c|c|}
\hline Sample & $\frac{\text { Temperature }}{{ }^{\circ} \mathrm{C}}$ & $\frac{t(\text { drying })}{\min }$ & $\frac{D_{\text {eff }} \cdot 10^{-9}}{\mathrm{~m}^{2} / \mathrm{s}}$ & $\frac{E_{\mathrm{a}}}{\mathrm{kJ} /(\mathrm{mol} \cdot \mathrm{K})}$ \\
\hline & 40 & 240 & 1.4 & \\
\hline \multirow[t]{3}{*}{ Control } & 50 & 180 & 2.5 & 37.5 \\
\hline & 60 & 150 & 2.6 & \\
\hline & 40 & 240 & 1.3 & \\
\hline \multirow[t]{3}{*}{ BL3 } & 50 & 180 & 1.8 & 26.0 \\
\hline & 60 & 150 & 2.1 & \\
\hline & 40 & 240 & 1.5 & \\
\hline \multirow[t]{2}{*}{ BL6 } & 50 & 180 & 1.8 & 34.6 \\
\hline & 60 & 150 & 2.2 & \\
\hline
\end{tabular}

$D_{\text {eff }}=$ effective diffusivity, $E_{\mathrm{a}}=$ activation energy, BL3=samples blanched at $98^{\circ} \mathrm{C}$ for $3 \mathrm{~min}, \mathrm{BL} 6=$ samples blanched at $98^{\circ} \mathrm{C}$ for $6 \mathrm{~min}$

peratures in the samples blanched for $3 \mathrm{~min}$. A decrease in moisture diffusivity was observed in all blanched samples as compared to the control (unblanched samples). Al- though Agarry et al. (23) reported that blanching prior to drying improves the effective moisture diffusivity, the current finding might be due to high draining of the additional water absorbed during blanching treatment. Continuous increase in the moisture diffusivity was observed with the increase in temperature during drying of control and blanched samples. Similar trend was recorded when drying grape seeds (16).

The activation energy range of 26.0 to $37.5 \mathrm{~kJ} / \mathrm{mol}$ was recorded. Higher value of activation energy was observed of the control (unblanched) samples with $37.5 \mathrm{~kJ} / \mathrm{mol}$, and slightly lower values of $34.6 \mathrm{~kJ} / \mathrm{mol}$ and $26.0 \mathrm{~kJ} / \mathrm{mol}$ were recorded of samples blanched for 3 and $6 \mathrm{~min}$. This result is in agreement with findings of Akintunde et al. (26), who reported similar trend of decreasing activation energy of the blanched samples of bell pepper in comparison with the unblanched samples. The activation energy of the control samples is almost similar to the finding of Darvish et al. (28), who reported a value of $36.40 \mathrm{~kJ} / \mathrm{mol}$ during thin layer drying of carrot slices. The values are similar to the activation energy obtained for the samples blanched for $3 \mathrm{~min}$. 


\section{Total anthocyanins}

In this study, the anthocyanin content was found to be $(31.68 \pm 0.45) \mathrm{mg}$ per $100 \mathrm{~g}$ of fresh mass, which is in agreement with the findings of Lazcano et al. (29), and Arscott and Tanumihardjo (30), who reported values of 38-98 and $0-350 \mathrm{mg}$ per $100 \mathrm{~g}$ of fresh mass in orange carrot and dark purple carrot respectively. Our findings contradict the results reported by Wu et al. (31) and Kammerer et al. (32), who reported higher values of 64.9 and $208-243 \mathrm{mg}$ per $100 \mathrm{~g}$ respectively. These differences are due to the fact that carrot roots are often of different colours depending on the tissue (33), ranging from purple-yellow, purple-orange, deep purple and purple haze. The root flesh (phloem) sometimes differs from the core (xylem).

Many researchers have investigated the degradation of anthocyanin pigment during thermal processing, which dramatically affects the colour and nutritional properties (34). Anthocyanins like other polyphenols degrade enzymatically in the presence of polyphenol oxidase and glycosidase, which catalyse the hydrolysis of anthocyanins to yield free sugar and aglycone (35). In this study, higher anthocyanin content was recorded at higher temperature $\left(60^{\circ} \mathrm{C}\right)$ in most of the samples including the control and samples blanched for 3 and $6 \mathrm{~min}$. Although the anthocyanin content was reported to degrade with higher temperature, the drying air temperature of $60^{\circ} \mathrm{C}$ was reported as the optimum for the retention of most phenolic compounds $(36,37)$. The anthocyanins from black carrot were reported to be relatively stable to heat and $\mathrm{pH}$ change compared to anthocyanins from other sources because of diacylation of anthocyanin structure (34). The results of the effect of pretreatment and drying temperature are shown in Table 4 . The effect of different drying temperatures was found to be significantly different at $p \leq 0.05$.

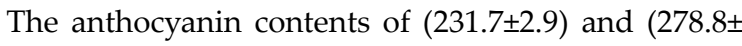
7.8) $\mathrm{mg}$ per $100 \mathrm{~g}$ were recorded in the samples blanched for 3 and $6 \mathrm{~min}$ and then dried at $60{ }^{\circ} \mathrm{C},(153.0 \pm 4.3)$ and $(247.0 \pm 5.5) \mathrm{mg}$ per $100 \mathrm{~g}$ were recorded at $40{ }^{\circ} \mathrm{C}$ respectively, which was lower than in the control samples: $(580.1 \pm 1.3)$ at $60^{\circ} \mathrm{C}$ and $(466.6 \pm 1.1) \mathrm{mg}$ per $100 \mathrm{~g}$ at $40^{\circ} \mathrm{C}$. The samples blanched for $3 \mathrm{~min}$ at $98^{\circ} \mathrm{C}$ and then dried at 60 and $50^{\circ} \mathrm{C}$ showed no significant decrease in the anthocyanin content at $\mathrm{p} \leq 0.05$. Despite the fact that some au-

Table 4. Effect of pretreatment and drying temperature on total anthocyanin content in control and blanched black carrot samples

\begin{tabular}{|c|c|c|c|}
\hline \multirow{3}{*}{ Sample } & \multicolumn{3}{|c|}{ Temperature $/{ }^{\circ} \mathrm{C}$} \\
\hline & 40 & 50 & 60 \\
\hline & \multicolumn{3}{|c|}{$w$ (anthocyanin) $/($ mg per $100 \mathrm{~g})$} \\
\hline Control & $(466.6 \pm 1.1)^{\mathrm{aC}}$ & $(421.3 \pm 4.0)^{\mathrm{aB}}$ & $(580.1 \pm 1.3)^{\mathrm{aA}}$ \\
\hline BL3 & $(153.0 \pm 4.3)^{\mathrm{bC}}$ & $(217.4 \pm 2.5)^{\mathrm{bB}}$ & $(231.7 \pm 2.9)^{\mathrm{bA}}$ \\
\hline BL6 & $(247.0 \pm 5.5)^{\mathrm{cB}}$ & $(282.6 \pm 2.5)^{\mathrm{cA}}$ & $(278.8 \pm 7.8)^{\mathrm{cA}}$ \\
\hline
\end{tabular}

BL3=samples blanched at $98^{\circ} \mathrm{C}$ for $3 \mathrm{~min}$, BL6=samples blanched at $98{ }^{\circ} \mathrm{C}$ for $6 \mathrm{~min}$. Data presented are the mean value of the triplicate determinations \pm standard deviation. In each column, values with the same capital letters are not significantly different at $\mathrm{p} \leq 0.05$ among blanching treatments. For each parameter, values with the same lower case letters in rows are not significantly different at $\mathrm{p} \leq 0.05$ among drying air temperatures thors reported that inclusion of mild heat treatment (at approx. $50^{\circ} \mathrm{C}$ ) can inactivate the degradation enzymes, the lower values recorded in the blanched samples were probably due to high leaching of the pigment observed during blanching. Wahyuningsih (38) recorded a decrease in the anthocyanin content of red turi (Sesbania grandiflora L. Pers) flower, which was ascribed to the leaching of anthocyanins into the blanching medium. Heating was also reported to encourage cellular fluids, containing phytochemicals, to diffuse from the plant cell to the water medium. Thus, the anthocyanin content in black carrot shreds after blanching is the net result of degradation due to heat treatment and leaching in the blanching water.

\section{Conclusion}

The drying time was found to be similar for blanched and unblanched samples (240, 180 and 150 min respectively at 40,50 and $60^{\circ} \mathrm{C}$ ). The drying rate constant of unblanched samples at 40 and $60^{\circ} \mathrm{C}$ was found to be slightly higher than of the samples blanched for $3 \mathrm{~min}$. The drying rate constant and effective moisture diffusivity were higher with the increased temperature. The values of 37.5, 34.6 and $26.0 \mathrm{~kJ} /(\mathrm{mol} \cdot \mathrm{K})$ were obtained. Page model fitted best to the drying of blanched and unblanched black carrot shreds at 40,50 and $60{ }^{\circ} \mathrm{C}$. In general, blanching of black carrots at $98^{\circ} \mathrm{C}$ for 3 and 6 min does not show significant changes in the drying time and effective diffusivity. The blanching treatment affected the anthocyanin content to a greater extent. The anthocyanin contents of (231.7 \pm 2.9$)$ and $(278.8 \pm 7.8) \mathrm{mg}$ per $100 \mathrm{~g}$ were recorded in samples blanched for 3 and 6 min and then dried at $60{ }^{\circ} \mathrm{C}$ respectively, (153.0 \pm 4.3$)$ and $(247.0 \pm 5.5) \mathrm{mg}$ per $100 \mathrm{~g}$ were recorded at $40{ }^{\circ} \mathrm{C}$ respectively, compared to the control sample with $(580.1 \pm 1.3) \mathrm{mg}$ per $100 \mathrm{~g}$ at $60^{\circ} \mathrm{C}$ and $(466.6 \pm$ 1.1) mg per $100 \mathrm{~g}$ at $40^{\circ} \mathrm{C}$.

\section{References}

1. Aghbashlo M, Kianmehr MH, Arabhosseini A, Nazghelichi T. Modelling the carrot thin layer drying in a semi-industrial continuous band dryer. Czech J Food Sci. 2011;29:528-38.

2. Huntrods D. Carrot profile. Agricultural Marketing Resource Center (AgMRC), Ames, IA, USA: Iowa State University; 2013. http://www.agmrc.org

3. Xiao HW, Gao ZJ, Lin H, Yang WX. Air impingement drying characteristics and quality of carrot cubes. J Food Proc Eng. 2010;33:899-918. http://dx.doi.org/10.1111/j.1745-4530.2008.00314.x

4. Erenturk S, Erenturk K. Comparison of genetic algorithm and neural network approach for the drying process of carrot. J Food Eng. 2007;78:905-12. http://dx.doi.org/10.1016/j.jfoodeng.2005.11.031

5. Ersus S, Yurdagel U. Microencapsulation of anthocyanin pigments of black carrot (Daucus carota L.) by spray drier. J Food Eng. 2006;80:805-12. http://dx.doi.org/10.1016/j.jfoodeng.2006.07.009

6. Kumar N, Sarkar BC, Sharma HK. Mathematical modelling of thin layer hot air drying of carrot pomace. J Food Sci Technol. 2012;49:33-41.

http://dx.doi.org/10.1007/s13197-011-0266-7

7. Dai JW, Rao JQ, Wang D, Xie L, Xiao HW, Liu YH, Gao ZJ. Process-based drying temperature and humidity integration control enhances drying kinetics of apricot halves. Dry Tech- 
nol. 2015;33:365-76.

http://dx.doi.org/10.1080/07373937.2014.954667

8. Bai JW, Sun DW, Xiao HW, Mujumdar AS, Gao ZJ. Novel high-humidity hot air impingement blanching (HHAIB) pretreatment enhances drying kinetics and color attributes of seedless grapes. Innov Food Sci Emerg Technol. 2013;20:230-7. http://dx.doi.org/10.1016/j.ifset.2013.08.011

9. Xiao HW, Lin H, Yao XD, Du ZL, Lou Z, Gao ZJ. Effects of different pretreatments on drying kinetics and quality of sweet potato bars undergoing air impingement drying. Int J Food Eng. 2009;5:1556-8.

http://dx.doi.org/10.2202/1556-3758.1758

10. Xiao HW, Yao XD, Lin H, Yang WX, Meng JS, Gao ZJ. Effect of SSB (superheated steam blanching) time and drying temperature on hot air impingement drying kinetics and quality attributes of yam slices. J Food Proc Eng. 2012;35:370-90. http://dx.doi.org/10.1111/j.1745-4530.2010.00594.x

11. Xiao HW, Bai JW, Sun DW, Gao ZJ. The application of superheated steam impingement blanching (SSIB) in agricultural products processing - a review. J Food Proc Eng. 2014;132:3947.

http://dx.doi.org/10.1016/j.jfoodeng.2014.01.032

12. Doymaz I. Evaluation of some thin-layer drying models of persimmon slices (Diospyros kaki L.). Energ Convers Manage. 2012;56:199-205. http://dx.doi.org/10.1016/j.enconman.2011.11.027

13. Dinrifo RR. Effects of pre-treatments on drying kinetics of sweet potato slices. Agric Eng Int: CIGR J. 2012;14:136-45.

14. Kulkarni SG, Vijayanand P. Effect of pretreatments on quality characteristics of dehydrated ivy gourd (Coccinia indica L.). Food Bioprocess Technol. 2012;5:593-600. http://dx.doi.org/10.1007/s11947-010-0339-z

15. Kumar PP, Kumaravel S, Lalitha C. Screening of antioxidant activity, total phenolics and GC-MS study of Vitex negundo. Afr J Biochem Res. 2010;4:191-5.

16. Roberts JS, Kidd DR, Padilla-Zakour O. Drying kinetics of grape seeds. J Food Eng. 2008;89:460-5. http://dx.doi.org/10.1016/j.jfoodeng.2008.05.030

17. Addo A, Bart-Plange A, Boakye DM. Drying characteristics of cap and stem of mushroom. J Sci Tech. 2009;29:88-95. http://dx.doi.org/10.4314/just.v29i2.46226

18. Saravacos GD, Maroulis ZB. Effect of surface-active agents on the dehydration of fruits and vegetables. Food Technol. 1962;16:91-3.

19. Tulek Y. Drying kinetics of oyster mushroom (Pleurotus ostreatus) in a convective hot air dryer. J Agric Tech. 2011;13: 655-64.

20. Crank J. The mathematics of diffusion. Oxford, UK: Clarendon Press; 1975.

21. Srivastava RP, Kumar S. Fruit and vegetable preservation: principle and practice. Lucknow, Uttar Pradesh, India: International Book Distribution Company; 2002.

22. SPSS (Data Analysis Software System), v. 22, IBM, Armonk, New York, USA; 2014.

http://www-01.ibm.com/software/analytics/spss/

23. Agarry SE, Ajani AO, Aremu MO, Thin layer drying kinetics of pineapple: effect of blanching temperature - time combination, Nig J Basic Appl Sci. 2013;21:1-10. http://dx.doi.org/10.4314/njbas.v20i1.1

24. Chawla C, Kaur D, Oberoi DPS, Sogi DS. Drying characteristics, sorption isotherms, and lycopene retention of tomato pulp. Drying Tech. 2008;26:1257-64. http://dx.doi.org/10.1080/07373930802307225
25. Maskan M. Drying, shrinkage and rehydration characteristics of kiwifruits during hot air and microwave drying. J Food Eng. 2001;48:177-82. http://dx.doi.org/10.1016/S0260-8774(00)00155-2

26. Akintunde TT, Akintunde BO, Fagbeja A. Effect of blanching methods on drying kinetics of bell pepper. AJFAND. 2011;11: 5457-74.

27. Roberts JS, Kidd DR, Padilla-Zakour O. Drying kinetics of grape seeds. J Food Eng. 2008;89:460-5. http://dx.doi.org/10.1016/j.jfoodeng.2008.05.030

28. Darvish H, Banakar A, Zarein M. Mathematical modelling and thin layer drying kinetics of carrot slices. GJSFR. 2012;12: $57-64$.

29. Lazcano CA, Yoo KS, Pike LM. A method for measuring anthocyanins after removing carotenes in purple colored carrots. Sci Hort. 2001;90:321-4. http://dx.doi.org/10.1016/S0304-4238(00)00248-X

30. Arscott SA, Tanumihardjo SA. Carrots of many colors provide basic nutrition and bioavailable phytochemicals acting as a functional food. Compr Rev Food Sci Food Saf. 2010;9: 223-39. http://dx.doi.org/10.1111/j.1541-4337.2009.00103.x

31. Wu X, Beecher GR, Holden JM, Haytowiyz DB, Gebhardt SE, Prior RL. Concentrations of anthocyanins in common foods in the United States and estimation of normal consumption. J Agric Food Chem. 2006;54:4069-75. http://dx.doi.org/ 10.1021/jf0603001

32. Kammerer D, Carle R, Schieber A. Quantification of anthocyanins in black carrot extracts (Daucus carota ssp. sativus var. atrorubens Alef.) and evaluation of their color properties. Eur Food Res Technol. 2004;219:479-86. http://dx.doi.org/10.1007/s00217-004-0976-4

33. Leja M, Kamińska I, Kramer M, Maksylewicz-Kaul A, Kammerer D, Carle R, Baranski R. The content of phenolic compounds and radical scavenging activity varies with carrot origin and root color. Plant Foods Hum Nutr. 2013;68:16370. http://dx.doi.org/10.1007/s11130-013-0351-3

34. Patras A, Brunton NP, O'Donnell C, Tiwari BK. Effect of thermal processing on anthocyanin stability in foods; mechanism and kinetics of degradation. Trends Food Sci Tech. 2010;21:3-11. http://dx.doi.org/10.1016/j.tifs.2009.07.004

35. Lohachoompol V. Effect of drying on anthocyanins in blueberries [PhD Thesis]. Sydney, Australia: The University of New South Wales; 2007.

36. Katsube T, Tsurunaga Y, Sugiyama M, Furuno T, Yamazaki Y. Effects of air-drying temperature on antioxidant capacity and stability of polyphenolic compounds in mulberry (Morus alba L.) leaves. Food Chem. 2009;113:964-9. http://dx.doi.org/10.1016/j.foodchem.2008.08.041

37. Wiriya P, Paiboon T, Somchart S. Effect of drying air temperature and chemical pretreatments on quality of dried chilli. Int Food Res J. 2009;16:441-54.

38. Wahyuningsih $\mathrm{D}$. The effect of method and blanching time on anthocyanin and ascorbic acid content of red Sesbania grandiflora L. (Pers) flower. Yogyakarta, Indonesia: Faculty of Agroindustry, Mercu Buana University; 2008. 